Zusammenfassung. Es wird über sieben der seltenen perilunären -transscaphoidären Luxationsfrakturen (de Quervain) berichtet. Die Ursache für diese Luxationsfrakturen war immer Sturz aus großer Höhe auf die hyperextendierte, ulnar abduzierte Hand. Die konservative Therapie war wegen Bandinterposition oder wegen eines rotierten Kahnbeinfragmentes immer erfolglos. Daher wurde das Mondbein blutig reponiert und das Kahnbein nach Strehli verschraubt. Nach vier Wochen Ruhigstellung im Rehbein-Düben-Gips waren alle Frakturen wieder belastungsfähig.

Schliisselwörter: Luxationsfrakturen der Hand, seltene - Behandlung, operative.

\title{
98. Sehneninterpositionsplastiken zum Ersatz nekrotisierter Carpalknochen
}

\author{
K. Wilhelm \\ Chirurgische Klinik der Universität München
}

\section{The Tendon-Interposition-Plastic as a Replacement for Partly Necrosed Scaphoid Pseudarthrosis or Lunato malacia}

\begin{abstract}
Summary. Aseptic bone necrosis of a fragment was seen in 10 out of 81 cases of scaphoid pseudarthrosis subjected to surgery, and also in 6 cases of lunatomalacia. Basing their method on Froimson's tendon interposition grafting for replacement of the trapezoid in arthrosis of the thumb joint, the author's team exstirpated the bionecrotic fragment of the scaphoid or the whole of the lunate bone, split the tendon of the flexor carpi radialis muscle or removed the whole length of the extensor carpi radialis brevis muscle, or in the cases with lunatomalacia, the tendon of the flexor palmaris longus muscle, and fixed the tendon in the cavity created by exstirpation of the bone or bone fragment. After a follow-up period ranging from a minimum of 6 months up to over 4 years, all patients were satisfied with the results and none had any symptoms. The function of the wrist was completely unimpaired.
\end{abstract}

Key words: Necrosis, bone - Tendon replacement - Lunatomalacia.

Zusammenfassung. Bei 81 operierten Naviculare-Pseudarthrosen lag in 10 Fällen eine aseptische Knochennekrose eines der Fragmente vor, ebenso in 6 Fällen einer Lunatum malazie. In Anlehnung an die Sehnen-Interpositionsplastik nach Froimson zum Ersatz des Trapezoids bei Daumensattelgelenksarthrosen wurden nach Exstirpation des bionekrotischen Navicularefragmentes oder der Lunatum-Nekrose, die Sehne des Musculus flexor carpi radialis längsgespalten oder die gesamte Länge der Sehne des Musculus extensor carpi radialis brevis bzw. bei der Lunatum malazie die Sehne des Musculus flexor palmaris longus gewonnen, am Muskelbauch abgetrennt und in der vorgegebenen Knochenhöhle fixiert. Nach einer Minimum-Beobachtungszeit von 6 Monaten bis über 4 Jahre waren alle Patienten mit dem Ergebnis zufrieden und beschwerdefrei. Die Handgelenksfunktion zeigte keine Einschränkung.

Schliisselwörter: Sehnen-Ersatzplastik - Bionekrose - Scaphoid - Lunatum malazie. 